enable one, listening to the latter, to hear the pitch of the former loudly reproduced when the magnet is struck like a tuning-fork so as to vibrate. This shows that the field of the magnet changes at the same rate as the vibrations.

Assume that the magnet becomes smaller and smaller until it is of the dimensions of an atom, say, for an approximation, the fifty-millionth of an inch. It would still have its field; it would still be elastic and capable of vibration, but at an enormously rapid rate; but its vibration would change its field in the same way, and so there would be formed those waves in the ether, which, because they are so short that they can affect he eye, we call light. The mechanical conceptions are legiimate, because based upon experiments having ranges through nearly the whole gamut as waves in ether.

The idea implies that every atom has what may be loosely called an electro-magnetic grip upon the whole of the ether, and any change in the former brings some change in the latter.

What I would like to emphasise is, that the action in the ether $s$ not electric action, but more properly the result of electromagnetic action. Whatever name be given to it, and however it comes about, there is no good reason for calling any kind of an ether action electrical.

Electric action, like magnetic action, begins and ends in matter. It is subject to transformations into thermal and mechanical actions, also into ether stress-right-handed or lefthanded-which, in turn, can similarly affect other matter, but with opposite polarities.

In his "Modern Views of Electricity," Prof. O. J. Lodge warns us, in a way I quite approve, that perhaps, after all, there is no such thing as electricity - that electrification and electric energy may be terms to be kept; but if electricity as a term be held to imply a force, a fluid, an imponderable, or a thing which could be described by some one who knew enough, then it has no degree of probability, for spinning atomic magnets seem capable of developing all the electrical phenomena we meet.

\section{UNIVERSITY AND EDUCATIONAL INTELLIGENCE.}

OxForD. - The election to the Professorship of Geology, vacant through the death of the late Prof. Green, will take place in Hilary Term, I897. Candidates are requested to send their applications, together with such evidence of their qualifications as they may desire, to the Registrar of the University on or before February I, I897. The Professor is required to lecture in Geology and Palæontology in two of the three University Terms, and to take charge of the Geological and Palæontological collections belonging to the University. $\mathrm{He}$ is entitled to receive $£ 400$ per annum from the University chest, which sum may be augmented to not less than $£ 7$ oo nor more than $£ 900$ per annum, if the University revenues permit, and unless provision for the payment of a corresponding amount shall have been made from some other source. Mr. W. B. Prowse is at present acting as Deputy Professor.

Mr. W. Ramsden has been elected Sheppard Medical Fellow of Pembroke College.

The Burdett-Coutts Scholarship will not be awarded for I896, the only candidate who presented himself having withdrawn before the close of the examination.

Prof. E. B. Youlton has recently returned to Oxford from a visit to America.

The following have been approved by Convocation as Examiners in Medicine for 1897,1898 , and 1899 :- I. For the first M.B. Examination: Prof. A. Macalister (Cambridge), in Human Anatomy. 2. For the second M.B. Examination : Prof. W. MacEwen (Glasgow), in Surgery. Dr. David Berry Hart (Edin.), in Midwifery.

The Junior Scientific Club held its first meeting this term on Friday, November 6, when Mr. D. Meinertzhagen (New Coll.) gave an interesting account of "Hawks and Hawking," and Mr. W. Garstang read a paper entitled, "The Ancestry of the Vertebrata as a Physiological Problem." The Committee for the present term is composed as follows:-President: H. P. Stevens. Treasurer: A. W. Brown. Secretaries: E. H. Hunt and I. B. Billinghurst. Editors : R. A. Buddicum, A. E. Boycott, A. C. Pilkington and A. R. Wilson.

NO. I 4 I 2 , VOL. 55$]$
CAmbringe.-An election to an Isaac Newton Studentship of 200 . a year for three years will be held in the Lent Term, 1897. The student is to devote himself to research in Cambridge in astronomy or physical optics. Candidates must be Cambridge B.A.s under the age of twenty-five on January $\mathbf{~}, \mathbf{1} 897$. Applications are to be sent to the Vice-Chancellor not later than January 25.

Mr. S. F. Harmer has been appointed Chairman of Examiners for the Natural Sciences Tripos, I897.

The Sedgwick Memorial Museum Syndicate propose that the site granted by the University near the new museums should be abandoned, and that a new site on the ground formerly belonging to Downing College, and recently acquired by the University, should be assigned instead. Some difference of opinion is likely to axise on the expediency of the proposal, which will involve the preparation of new plans and further delay.

The following awards in Natural Science were made at Trinity College on November I4: Major Scholarship (8ol.), O. W. Richardson, Batley School ; Minor Scholarship (5ol.), G. Barger, High School, The Hague; Sizarship, R. E. Robinson, Newcastle (Staffs.) School ; Exhibitions (40\%), H. Gaskell (Rugby), G. Savory (Harrow), and E. E. Walker (Bradford).

Dr. Phisipp Lenard has removed from Aachen, to take up a professorship of theoretical physics in the University of Heidelberg.

Mr. Thomas TICKLE, of the School of Pharmacy, has been elected to the Salters' Company Research Fellowship in Chemistry, tenable in the Research Laboratory of the Pharmaceutical Society.

WI'T reference to the note on the University College, Bristol, in last week's NATURE (p. 46) we are informed that the Bristol Town Council has altogether given the College 4000\%. The Council gave 2000l. towards the Engineering wing, just opened by Mr. Wolfe Barry, and has recently granted another $2000 l$. towards the capital sum of $10,000 \%$. which the College authorities are trying to raise.

A RECENT law restored to the various French University centres the title of University, together with some measure of self-government; whereas since the time of Napoleon they had simply been sections of one University, and with the title of faculties. The Times correspondent at Paris states that arrangements have been made to celebrate the opening of term under the new system to-day by a gathering of professors and students, over which M. Faure will preside.

AT the distribution of prizes at the Barking Technical School, by the Countess of Warwick, on November i I, an address on the technical education movement was delivered by Prof. R. Meldola, F.R.S., of the Technical Instruction Committee of the Essex County Council. In the course of his remarks, the speaker deplored the line of action so generally followed through. out Essex, as well as in other counties, and which resulted in the greater part of the fund at their disposal being frittered away in small efforts at evening instruction. The main portion of the address was devoted to pointing out the true position of evening work in the scheme of technical education. It was contended that this kind of instruction, although to a certain extent useful, and even necessary, was not in itself more than an aid to true technical education, and could not, unless crowned by higher efforts, be of any use to the country at large as a means of enabling us to compete successfully with our foreign rivals in manufacturing and agricultural industries. For this reason the speaker, while admitting the good work which had been hitherto carried on at Barking, felt bound to express his regret that so much of the resources available for technical instruction had been used up in the formation of classes for cookery, ambulance, dressmaking, and other subjects, which, in his opinion, should have been sub. sidised from other sources, or else taught in schools. Reference was made to the recent correspondence in the papers on the state of technical education on the continent as compared with that in this country, and figures were quoted showing the relative amount of endowment of technical high schools and polytechnics in Germany and Switzerland as compared with those in England. The speaker described from personal experience, and in high terms of praise, the zeal and energy with which men engaged all day in arduous work will come to evening classes to improve their knowledge of scientific principles. He felt sure, however, that such men were sensible enough to see how hopeless it was to make headway against the expert knowledge of highly-trained and specialised students from the German schools, who devote 
the best years of their youth and manhood to acquiring a competent knowledge of the science of their subject, unless they (the evening students of this country) had, as the leaders of their industries, men of an equal training to that of their competitors. The general tendency of Prof. Meldola's remarks was to encourage more concentrated effort on the part of such large urban districts as Barking, East Ham, Dagenham, and surrounding parishes, which contain a population of some 40,000 people, and he expressed the hope that the local committees would see their way to federation and joint action in the carrying on of organised day classes, as well as the evening work upon which they had hitherto concentrated their efforts. At the conclusion of the address the Countess of Warwick, in a short and forcible speech, also urged the importance of organised day work, and endorsed the wish expressed by Prof. Meldola that Barking would be in possession of such schools at no very distant period. Mr. W Bewers, to whom the success of the Barking School is so largely due, and who is chairman of the local committee, presided at the meeting.

\section{SOCIETIES AND ACADEMIES.}

\section{LONDON.}

Physical Society, November I3. - Captain Abney, President in the chair.-A paper on some experiments with Rontgen's radiation, by Prof. Threlfall and Mr. Pollock, was, in the absence of the authors, read by the Secretary. - The authors describe a form of Crookes' tube which, while it can be made by any one capable of the most elementary glass-blowing, gives a plentiful supply of Röntgen rays. The results of their experiments may be summed up as follows: (I) The Röntgen radiation does not consist in the projection of gaseous matter, or, if it does, the amount of such matter involved is extraordinarily small. (2) The Röntgen radiation does not consist in the projection of æther streams having a velocity above a couple of hundred metres per second ; this is true, whether the radiation takes place in air or in benzene. (3) The properties of the æther regarded as determining the velocity of electromagnetic waves are not greatly changed (i.e. not at all within our experimental limits) by the Röntgen radiation; and this applies alike to the æther in air and in benzene. (4) A selenium cell composed of platinum electrodes and highly purified selenium, is affected by Röntgen radiation to an extent which is comparable with the effect produced by diffused daylight. (5) No permanent or temporary electromotive force is set up in a selenium cell by the Röntgen radiation. The authors have come to the first conclusion by exposing an exhausted tube placed in parallel with a spark-gap, so adjusted that the spark just passes over the gap rather than through the tube, to the Röntgen radiation. They find that a vacuum tube in parallel with a spark-gap is very sensitive to changes in pressure within the tube. Conclusions (2) and (3) were arrived at by using Michelson's arrangements for the interference of two beams of iight. Mr. Shelford Bidwell said he had made some experiments on the effect of Rontgen rays on the resistance of selenium, but with a negative result, although he would have detected a much smaller change than that found by the authors. It might be that this difference was due to the tube, for, in his experiment, the radiation started from a platinum plate within the tube, while in the authors' arrangement the radiation starts from where the kathode rays strike the glass of the tube. Prof. Silvanus Thompson said there were a number of points with reference to the Röntgen radiation which required clearing up. For instance, the suggestion that they were vortices in the rther had not been tested. Again, Lafay says that if the rays are passed through a metal screen which is charged with electricity, then the rays can be deflected by a magnet. $\mathrm{He}$ (Prof. Thompson) had not been able to repeat this experiment, neither had he that of Galitzine on the polarisation of the rays by tourmaline: The statement of Prof. J. J. Thomson, that under the influence of the radiation paraffin became a conductor, had not been satisfactorily proved. As to the wave-length, while some observers obtained values about one-tenth that of the extreme violet, another had obtained a value greater than that of the extreme red. "He (the speaker) did not understand the authors' device for detecting changes in the vacuum of a tube, since every one who has worked with Crookes' tubes has found that the resistance is always greater for a spark in one direction than the other, and also varies with the battery power employed. Lenard, adopting Hertz's arrangement, uses as anode a cylinder surrounding the kathode (a disc), the idea being that by using such a symmetrical arrangement the kathode radiation was more homogeneous. It might be advisable, when seeking to produce homogeneous Röntgen rays, to adopt such a symmetrical arrangement.-Mr. Bryan then read a paper, by himself and Dr. Barton, on the absorption of electrical waves along wires by a terminal bridge. The authors employ, for the generation of the oscillations, an arrangement of the same description as that used by Bjerknes, the waves being propagated along two parallel wires about I $16 \mathrm{~m}$. long. In order to measure the waves, they use a small electrometer with an uncharged needle. The resistances employed to form the bridge consist of pencil-marks on ground glass. Bridges of three resistances have been examined, one having, as nearly as may be, the resistance necessary, according to Heaviside's theory, to give complete extinction of the reflected wave, and, of the others, one was of higher, and the other of lower resistance. In each case the results confirm the theory, and it is thus experimentally proved that by using a bridge of this description the reflected train of waves can be completely extinguished. Mr. Blakesley asked if the authors had made any allowance for the capacity of the wires. Mr. Campbell asked if the resistances given were expressed in ohms or in electro-magnetic units. Mr. Bodwell asked if the authors had found that the pencil-trace resistances obeyed Ohm's law. He had found that if you balanced with one cell in the battery circuit, then, on increasing the battery power to two cells, the resistance altered. Mr. Appleyard suggested that the variation was caused by the contacts at the ends not being good. Mr. Campbell said the same variation occurred in the case of mixtures of clay and plumbago, where the contacts were quite good. Mr. Carter suggested electroplating the ends to give good contact. Mr. Bryan, in his reply, said that they had not considered the question of capacity, and that, in their case, they did not require to know the resistance very accurately.

Entomological Society, November 4.-Prof. Raphael Meldola, F.R.S., President, in the chair.-Mr. McLachlan exhibited a collection of the cast nymph-skins of more than one-third of the species of European dragon-flies from the Département de l'Indre, France, sent to him by M. René Martin. Two or three of the species had been reared in an aquarium, but the identification of most of them had been secured by finding the imago drying its wings in the immediate vicinity of the cast skin. - Mr. R. Adkin exhibited a long series of Acidalia marginepunctata taken on the sea-coast at Eastbourne, Sussex, during the past eight summers.-Mr. Horace St. Iohn Donisthorpe exhibited a female specimen of Dytiscus circumcinctus, Ahr., with elytra resembling in form those of the male. He said the specimen had been taken in Wicken Fen in August last. - Mr. Tutt exhibited a specimen of Mellinia ocellaris recently taken near Southend, together with a specimen of $M$. gilvago for comparison; also four specimens of Argyresthia atmoriella taken by Mr. Atmore last June at Lynn, Norfolk. Mr. Tutt also exhibited a long series of a Melampias which he had captured at Le Lautaret in the Dauphiné Alps, at an elevation of $7000-8000$ feet. He observed that the specimens exhibited were peculiar in some very important particulars, combining some of the characteristics of Erebia (Melampias) melampus, and $M$. pharte. He said his attention had been first drawn to this form by some fine examples captured by Dr. Chapman and himself on Mont de la Saxe in 1895 . Compared with the Tyrolean examples of $M$. melampus, this form showed a tendency to a lengthening of the forewings and to an obsolescence of the black dots, thus approaching $M$. pharte, but the females presented none of the typical characters of the female of $M$. pharte. On the whole, he feit satisfied that the Mont de la Saxe specimens were a form of $M$. melampus. Mr. Elwes observed that though all the continental butterflies had been so long studied by European entomologists; he did not think the form exhibited by Mr. Tutt had been hitherto noticed.-Mr. E. Ernest Green exhibited a typical specimen of Ephyra omicronaria, together with what he believed to be a remarkable melanic variety of the same species, taken by Dr. Dudley Wright at Pegwell Bay, near. Ramsgate, in September last. Some of the Fellows present, after an examina. tion of the specimen, expressed an opinion that it was a variety of an Acidalia, and not of Ephyra onicronaria.

Anthropological Institute; November 10.-Mr. E. W. Bräbrook, President, in the chair.-Mr. P. L. Sclater exhibited a draught-board from Nyasaland; Mr. C. H. Read, a dance-mask

NO. I 4 I 2, VOL. 55$]$ 